\title{
冷却トラップの熱損 失*
}

\author{
平野 治男 ${ }^{* *}$ 吉村 長光** \\ （昭和 55 年 12 月 15 日 受理）
}

\author{
Thermal Loss of a Cold Trap \\ Haruo HIRANO and Nagamitsu YOSHIMURA
}

(JEOL Ltd., Akishima-shi, Tokyo)

(Received December 15, 1980)

\section{1. 序}

電子顕微鏡の排気系に用いられる冷却トラップは，下 記の条件を満たす必要がある.

1) 液体窒素の入手が困難な地域で電子顕微鏡が使用 される場合, 冷却トラップのリザーバは排気抵抗にな る.この場合はリザーバを取りはずして排気抵抗を小さ くする必要がある．\&た，リザーバのクリーニングのた めにもリザーバの取りはずしが容易であることが要求さ れる.

2）電子顕微鏡は連続運転される場合が多い. 従って リザーバの液体窒素保持時間は20時間以上必要である.

3) 水蒸気やハイドロカーボンに対する凝縮排気速度 は十分大きくなければならない.

以上の条件を考慮して, 電子顕微鏡用冷却トラップを 製作した. この冷却トラップが上記条件を満足している ことを実験により確認した.

\section{2. 構造}

Fig. 1 に今回製作した冷却トラップの構造を示す.

トラップは，リザーバが上部から容易に取りはずせる 構造をしている. 熱伝導損失を小さくするため, リザー バを薄肉 $(0.5 \mathrm{t})$ のステンレス鋼で作り,上部を細く絞 った。 また輻射損失を小さくするため，反射板を組み込 んだ. 反射板の被排気系側には十分大きな排気孔を設け た.これは被排気系からくる気体分子を効率よくリザー バの冷却面に衝突させるためである.

*昭和 55 年11月 12 日 第21回真空に関する連合講演会で講演 $(12 a-1)$

**日本電子株式会社（東京都昭島市中神町1418）

\section{3. 液体窒素の保持時間}

序の第 2 項の必要性から, リザーバの液体窒素保持時

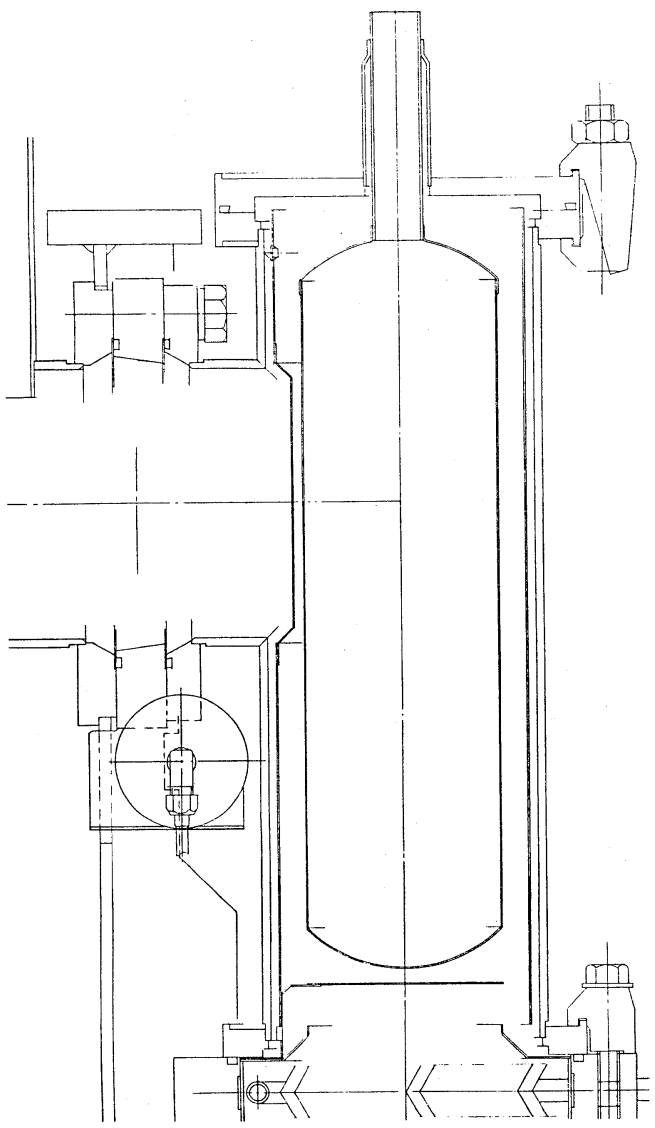

Fig. 1 Construction of $\mathrm{LN}_{2}$ cold trap 


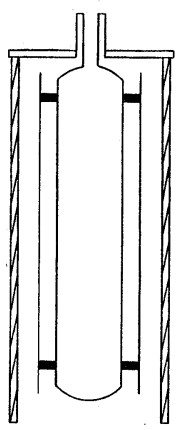

Case 1

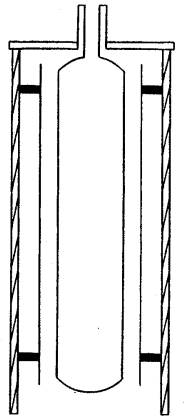

Case 2

\begin{tabular}{|l|c|c|c|c|c|}
\hline Reflector & \multicolumn{2}{|c|}{ without ref. } & \multicolumn{3}{|c|}{ with ref. } \\
\hline Surface condition & Meas. & Cal. & Case 1 & Case2 & Cal. \\
\hline 6.3 s & 24 & 26 & 34 & 36 & 46 \\
\hline wrapped with Al foil & 39 & 37 & 42 & 52 & 55 \\
\hline
\end{tabular}

Fig. $2 \mathrm{LN}_{2}$ Holding Time

間を測定した. リザーバの表面粗さは $6.3 \mathrm{~S}$ であった. 輻射損失を小さくして，リザーバの液体窒素保持時間を 長くする目的で，リザーバの表面及び反射板の表面にア ルミ管を巻き付けることも検討した，また，反射板取り 付け部では熱伝導による熱リークが生じ, この熱量がリ ザーバ（液体窒素温度）にリークするか外壁（室温）に
リークするかによって熱輻射による熱損失量が異なるこ とは, 熱伝導, 熱輻射の理論式から分かる. この熱損失 量の違いによって液体窒素保持時間が変化する. これ （液体空素保持時間の違い）がどの程度であるかをも測 定した. 反射板の取り付け方及び，上に述べた種々の状 態で測定したリザーバの液体窒素保持時間と熱伝導・熱 輻射の理論式より算出した計算值（液体窒素保持時間の 計算值）を Fig. 2 に示す. なお, 反射板を組み込んだ場 合の計算では, 反射板取り付け部での熱リークは無いと 仮定している.

測定の結果，リザーバの表面粗さ $6.3 \mathrm{~S}$ で，Case 2 の 状態において液体窒素保持時間は 36 時間であった。 Fig. 2 に示すように, Case 1 の状態においても十分な值が得 られたが，液体窒素保持時間を最大限長くするといら点 から，我々は Case 2 を採用した. リザーバの容量は 1.3 lである.

リザーバの表面にアルミ簿を巻き付けるとさらに液体 窒素保持時間を延ばすことができたが，実験の結果，ト ラップ動作中に圧力上昇が観察され，トラップとしては 不適当と判断した. 上記の状態 (リザーバの表面粗さ $6.3 \mathrm{~S}$, 反射板は Case 2 の様に取り付ける) でこの冷却 トラップは序の第 2 項の条件を十分に満足していること

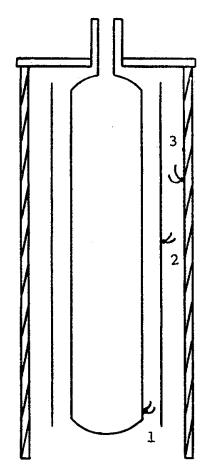

\begin{tabular}{|c|c|c|}
\hline Position & Measurement & Calculation \\
\hline 1 & $79^{\circ} \mathrm{K}$ & $79^{\circ} \mathrm{K}$ \\
\hline 2 & $270^{\circ} \mathrm{K}$ & $254^{\circ} \mathrm{K}$ \\
\hline 3 & $294^{\circ} \mathrm{K}$ & $294^{\circ} \mathrm{K}$ \\
\hline
\end{tabular}

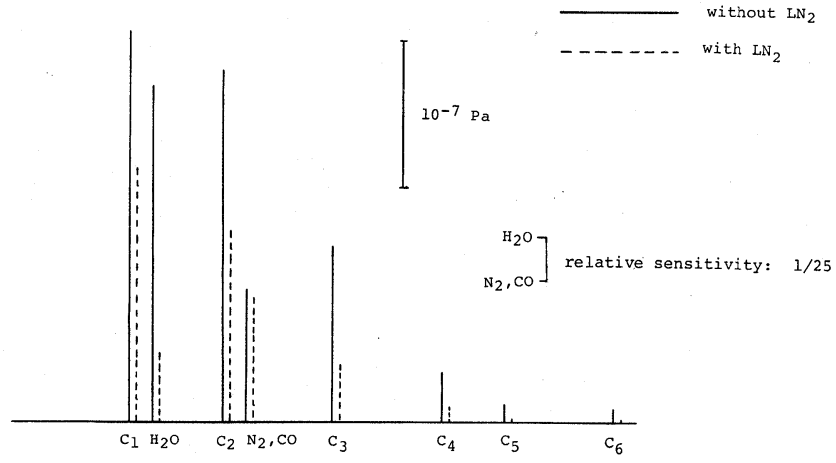

Fig. 4 Residual gas analysis
Fig. 3 Temperature in case 2, 6.3S 
が判明した。 この時, 液体窒素の消費量は $36 \mathrm{~m} l / \mathrm{H}$ で あった。

\section{4. 反射板の温度測定}

Case 2 の状態で, 液体窒素保持時間に対しては満足す べき結果が得られた．しかし計算值と比較すれば， $30 \%$ の差がある，この原因の一つは，前に述べたように，反 射板取り付け部での熱リークである。これを反射板の温 度測定により検討した. 測定点と測定結果，及び計算値 （反射板取り付け部で熱リークは無いと仮定）をFig. 3 に示す．測定に扮ける熱伝導・熱輻射に関する条件は， リザーバ表面粗さ $6.3 \mathrm{~S}$ (アルミ䈃は巻き付けていない), 反射板は外壁に固定 (Case 2) である.

反射板の温度を計算するには，リザーバ及び外壁の温 度が必要である. Fig. 3 の計算では，この值に実測值を 採用した. それ故, 反射板取り付け部で熱リークが無け れば，反射板の実測温度は計算值にほぼ近い值を示すは ずである. 測定及び計算の結果, 反射板の温度は実測值 $270^{\circ} \mathrm{K}$, 計算值 $254^{\circ} \mathrm{K} ゙$ あった. 実測值は計算值より $16^{\circ}$ 高温側にずれている. 以上の結果, リザーバの液体窒素 保持時間測定における $30 \%$ の差(実測值と計算值の差) は 反射板取り付け部での熱リークにより生じたものと判断
できる：な抢，ガス分子による熱損失は無視している． 反射板の温度は, 液体窒素冷却面の温度 (リザーバの 表面温度）よりも外壁の温度（室温）に近いため，反射 板でのトラップ効果は期待できない，我々は反射板の被 排気系側に十分大きな排気孔を設け，この点に対処し た.

\section{5. 残留ガス分析}

この冷却トラップの残留ガス分析の結果をFig. 4 に示 す.

電子顕微鏡で問題になる水勒気，ハイドロカーボンに 対し, 水蒸気は $1 / 5$ に, コンタミネーションの原因となる 分子量の大きいハイドロカーボンは $1 / 3$ に減少している.

\section{6. 結 論}

今回製作した冷却トラップは，反射板を外壁に取り付 けた状態で十分な液体窒素保持時間を得た. また残留ガ ス分析の結果は，水蒸気やハイドロカーボンに対する凝 縮排気速度が十分であることを示している．以上の結 果, この冷却トラップは, Fig. 1 亿示した構成で, 電子 顕微鏡用冷却トラップとして十分に機能を発揮すること が判明した. 